\title{
High quality draft genomes of the Mycoplasma mycoides subsp. mycoides challenge strains Afadé and B237
}

\author{
Anne Fischer ${ }^{1,2^{*}}$, Ivette Santana-Cruz ${ }^{3}$, Jan Hegerman ${ }^{4,5,6}$, Hadrien Gourlé ${ }^{7}$, Elise Schieck', Mathieu Lambert ${ }^{7}$, \\ Suvarna Nadendla ${ }^{3}$, Hezron Wesonga ${ }^{8}$, Rachel A. Miller ${ }^{1,9}$, Sanjay Vashee ${ }^{10}$, Johann Weber ${ }^{11}$, Jochen Meens ${ }^{12}$, \\ Joachim Frey ${ }^{13}$ and Joerg Jores ${ }^{1,13^{*}}$
}

\begin{abstract}
Members of the Mycoplasma mycoides cluster' represent important livestock pathogens worldwide. Mycoplasma mycoides subsp. mycoides is the etiologic agent of contagious bovine pleuropneumonia (CBPP), which is still endemic in many parts of Africa. We report the genome sequences and annotation of two frequently used challenge strains of Mycoplasma mycoides subsp. mycoides, Afadé and B237. The information provided will enable downstream 'omics' applications such as proteomics, transcriptomics and reverse vaccinology approaches. Despite the absence of Mycoplasma pneumoniae like cyto-adhesion encoding genes, the two strains showed the presence of protrusions. This phenotype is likely encoded by another set of genes.
\end{abstract}

Keywords: Mycoplasma mycoides subsp. mycoides, Challenge strain, Genome, Contagious bovine pleuropneumonia, Protrusion

\section{Introduction}

The 'Mycoplasma mycoides cluster' comprises five species/subspecies, Mycoplasma mycoides subsp. mycoides, Mycoplasma leachii, Mycoplasma mycoides subsp. capri, Mycoplasma capricolum subsp. capripneumoniae and Mycoplasma capricolum subsp. capricolum [1, 2]. Among them, Mycoplasma mycoides subsp. mycoides, the causative agent of contagious bovine pleuropneumonia (CBPP), is an economically very important bacterial bovine pathogen in sub-Saharan Africa. CBPP was first described in Europe already in 1773 [3], and the causative Mycoplasma was then cultivated and characterized in 1898 in Europe [4]. It has been shown that it spread from Europe to North America, Africa, Australia and Asia via livestock movements. Currently the disease is endemic and widespread in subSaharan Africa, ranging from western, central to eastern Africa. In Europe the last outbreaks were reported in Spain, Italy, Portugal and France in the 1980s and 1990s [5]. In comparison to other members of the 'Mycoplasma mycoides

\footnotetext{
* Correspondence: jores.anne@gmail.com; jores.anne@gmail.com 'International Livestock Research Institute, PO Box 3070900100 Nairobi, Kenya

Full list of author information is available at the end of the article
}

cluster, with the exception of Mycoplasma capricolum subsp. capripneumoniae, Mycoplasma mycoides subsp. mycoides shows limited sequence diversity, probably due to its recent emergence about 300 years ago $[5,6]$.

Currently the complete genomes of only three $\mathrm{Myco}$ plasma mycoides subsp. mycoides strains have been deposited in GenBank, the type strain PG1 [7], which is often used in laboratories but which is considered to be avirulent, the Australian outbreak strain Gladysdale [8] and a European outbreak strain 57/13 [9]. PG1 has been shown to differ genetically and phenotypically from field stains of Mycoplasma mycoides subsp. mycoides, showing attenuated cytotoxicity and reduced adhesion to bovine epithelial cells $[5,10,11]$, most likely because of the multiple in vitro passages this strain underwent before being deposited in the strain collections. In particular strain PG1 contains 2 large $24 \mathrm{~kb}$ repeats while 27 field strains isolated from three different continents only contain one [11]. Strain Gladysdale was isolated from Australia around 1953 [12]. Strain 57/13 was isolated in Italy in 1992. Neither of these three strains, therefore, represent virulent African strains. The genetic diversity of Mycoplasma mycoides subsp. mycoides strains has been reported to be highest in Africa 
[5] where the disease is present in many countries of subSaharan Africa [13]. We sequenced and annotated the genomes of two virulent African strains Afadé and B237, which are frequently used as challenge strains in animal experiments [14-18]. The strains have been re-isolated directly from experimentally infected animals and have not been exposed to subsequent passaging beyond filtercloning to promote uniformity before genomic DNA was isolated for sequencing. The genomic sequence information from this work will contribute to comparative genomic analyses and therefore the characterization of the core and pan genome of the 'Mycoplasma mycoides cluster' and Mycoplasma mycoides subsp. mycoides in particular. The genomic information will also be useful for downstream 'omics' applications, such as proteomics, transcriptomics and reverse vaccinology approaches.

\section{Organism information} Classification and features

Mycoplasma mycoides subsp. mycoides is an obligate parasite, which resides in the respiratory tract of animals. It is a non-motile, non-sporulating bacterium. It lacks a cell wall and has a pleomorphic shape. Transmission electron microscopy images were generated for both Afadé and B237 strains (Fig. 1). Cell pellets were fixed in $150 \mathrm{mM}$ HEPES, pH 7.35, containing $1.5 \%$ formaldehyde and $1.5 \%$ glutaraldehyde for $30 \mathrm{~min}$ at RT and at $4{ }^{\circ}$ over night. After dehydration in acetone and embedding in EPON, ultrathin sections of $40 \mathrm{~nm}$ were mounted on formvar-coated coppergrids, poststained with uranyl acetate and lead citrate [19] and observed in a Morgagni TEM (FEI). Images were taken with a side mounted Veleta CCD camera.

Interestingly the transmission electron microscopy revealed protrusions resembling the attachment organelle observed in Mycoplasma pneumonia [20-23]. The physiological function of these protrusions and branching phenotype needs to be defined in future studies. The general features of Mycoplasma mycoides subsp. mycoides strains Afadé and B237 are presented in Table 1 and Appendix: Table 6.

We previously confirmed that both strains Afadé and B237 are Mycoplasma mycoides subsp. mycoides using phenotypic growth characteristics, species-specific PCR and a Multi-Locus Sequence Typing (MLST) method $[5,6]$. Mycoplasma mycoides subsp. mycoides strain Afadé originates from Northern Cameroon and was isolated at the Farcha laboratories in Tchad in 1965 [24]. It has since served for several experimental infections [14-18]. The filter-cloned strains used for this sequence analysis were reisolated from experimentally infected cattle [14, 17] that showed severe clinical signs and pathomorphologic lesions typical of CBPP. Mycoplasma mycoides subsp. mycoides strain B237 was originally isolated in 1997 in Thika, Kenya, by the Kenya Agricultural Research Institute (KARI).
Figure 2 shows a phylogenetic tree of the 16S rRNA sequences. 16S rRNA gene sequences from Mycoplasma mycoides subsp. mycoides strains Gladysdale, 57/13 and PG1, Mycoplasma mycoides capri strains 95010 and GM12, Mycoplasma capricolum subsp. capricolum strain ATCC27343, Mycoplasma capricolum subsp. capripneumoniae strain M1601, Mycoplasma leachii strains 99/ 014/6 and PG50, Mycoplasma feriruminatoris strain G5847 (Accession numbers: CP002107, CP010267, NC_005364, NC_015431, NZ_CP001668, NC_007633, CM001150, NC_017521, ANFU01000033, NC_014751, respectively) were retrieved from GenBank. All Mycoplasma genome sequences retrieved from GenBank have two copies of $16 \mathrm{~S}$ rRNA each, with the exception of Mycoplasma feriruminatoris, where two copies are present but are not resolved in the draft genome [25].

\section{Genome sequencing information Genome project history}

The sequencing and quality assurance was performed at Lausanne Genomic Technologies Facility, Center for Integrative Genomics, University of Lausanne, Switzerland. The assemblies and finishing were done at the Institute for Genome Sciences and International Livestock Research Institute. Functional annotation was produced by the Institute for Genome Sciences Analysis Engine [26] (http://www.igs.umaryland.edu/research/bioinformatics/ analysis/index.php). Table 2 presents the project information and its association with MIGS version 2.0 compliance [27].

\section{Growth conditions and genomic DNA preparation}

Both strains were grown in PPLO medium (Difco, Cat no. 255420) supplemented with $20 \%$ heat-inactivated horse serum (Sigma, Cat. No. H1138), 0.5 \% glucose, $0.03 \%$ penicillin G, $20 \mathrm{mg} / \mathrm{ml}$ thallium acetate and $0.9 \mathrm{~g} / \mathrm{L}$ yeast extract at $37^{\circ} \mathrm{C}$.

Liquid cultures of Mycoplasma were filter cloned using a $0.22 \mu \mathrm{m}$ filter to disrupt possible cell aggregates. A serial dilution $(1 / 10$ - 1/10,000,000,000) was made immediately and $50 \mu \mathrm{l}$ was plated on PPLO agar.

After 3-4 days of incubation at $37^{\circ} \mathrm{C}$, a single colony was picked and was used to inoculate $4 \mathrm{ml}$ of PPLO medium which was aliquoted and stored at $-80{ }^{\circ} \mathrm{C}$.

Filter cloned Mycoplasma were grown overnight in $100 \mathrm{ml}$ PPLO medium at $37^{\circ} \mathrm{C}$. Before entering the stationary growth phase the culture was centrifuged at $2,862 \mathrm{~g}$ for $1 \mathrm{~h}$, and the pellet was resuspended in $2.5 \mathrm{ml}$ of TNE buffer (0.01 M Tris-HCl, pH 8.0; $0.01 \mathrm{M} \mathrm{NaCl}$; 0.01 M EDTA). Subsequently $50 \mu \mathrm{l}$ SDS $(10 \%)$ and $50 \mu$ l Proteinase K $(20 \mathrm{mg} / \mathrm{ml})$ were added and the tubes were incubated at $37^{\circ} \mathrm{C}$ for $2 \mathrm{~h}$. After addition of $26 \mu \mathrm{l}$ of $100 \mathrm{mM}$ PMSF the tubes were incubated $15 \mathrm{~min}$ at room temperature, $25 \mu \mathrm{l}$ of RNase A (10 mg/ml) was added, followed by incubation at $37^{\circ} \mathrm{C}$ for $1 \mathrm{hr}$. Sodium acetate and Phenol Saturated Buffer 


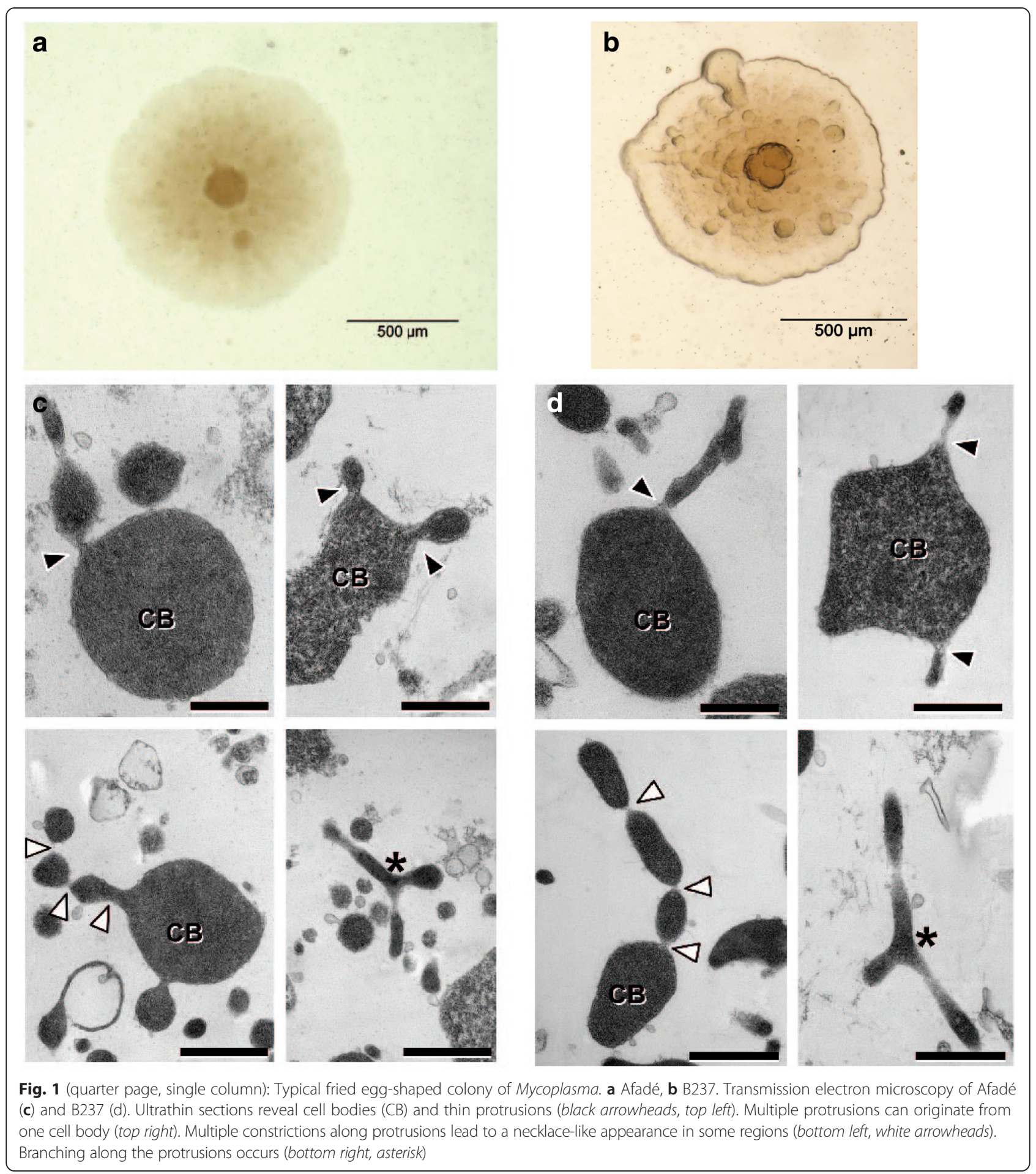

was added $(25 \mu \mathrm{l}$ of $\mathrm{NaOAc} 1.5 \mathrm{M}$ pH 5.2, and $2250 \mu \mathrm{l}$ of Phenol), the solution was mixed by vortexing and centrifuged at 15,870 g for $10 \mathrm{~min}$. The top phase was transferred to a new tube and mixed with Phenol:Chloroform:Isoamyl Alcohol Buffer (Phenol:Chloroform:Isoamyl Alcohol; 25:24:1) followed by another centrifugation at 15,870 $\mathrm{g}$ for $10 \mathrm{~min}$ and again the top phase was transferred to a new tube. Finally, the DNA was precipitated with isopropanol, washed with $70 \%$ ethanol, dried and resuspended in $200 \mu \mathrm{l}$ of $2 \mathrm{mM}$ Tris, $0.2 \mathrm{mM}$ EDTA.

\section{Genome sequencing and assembly}

The genome sequence of Mycoplasma mycoides subsp. mycoides strain Afadé was generated using a combination 
Table 1 Classification and general features of Mycoplasma mycoides subsp. mycoides strains Afadé and B237

\begin{tabular}{|c|c|c|c|}
\hline MIGS ID & Property & Term & Evidence code $\mathrm{e}^{\mathrm{a}}$ \\
\hline & Classification & Domain Bacteria & TAS [39] \\
\hline & & Phylum Firmicutes & TAS [40] \\
\hline & & Class Tenericutes & TAS [41-44] \\
\hline & & Order Mycoplasmatales & $\operatorname{TAS}[45,46]$ \\
\hline & & Family Mycoplasmataceae & TAS [46] \\
\hline & & Genus Mycoplasma & IDA \\
\hline & & Species Mycoplasma mycoides & IDA [4] \\
\hline & & Subspecies Mycoplasma mycoides subsp. mycoides & IDA [4] \\
\hline & & Strains Afadé and B237 & \\
\hline & Cell shape & Pleomorph & IDA \\
\hline & Motility & Nonmotile & IDA \\
\hline & Sporulation & Nonspore-forming & IDA \\
\hline & Temperature range & $30-42{ }^{\circ} \mathrm{C}$ & IDA \\
\hline & Optimum temperature & $38.5^{\circ} \mathrm{C}$ & IDA \\
\hline & $\mathrm{pH}$ range; optimum & $6.5-8.5 ; 7.5$ & IDA \\
\hline & Carbon Source & $\begin{array}{l}\text { Not determined since strains require complex media } \\
\text { including serum for growth }\end{array}$ & - \\
\hline & Energy Source & $\begin{array}{l}\text { Not determined since strains require complex media } \\
\text { including serum for growth }\end{array}$ & - \\
\hline MIGS-6 & Habitat & Respiratory tract & IDA \\
\hline MIGS-6.3 & Salinity & $0.09 \%$, no growth was obtained at salinities $\geq 0.5 \mathrm{M} \mathrm{NaCl}$ & IDA \\
\hline MIGS-22 & Oxygen Requirement & Facultative anaerobe & [42] \\
\hline MIGS-15 & Biotic relationship & Pathogen & - \\
\hline MIGS-14 & Pathogenicity & Etiological agent of Contagious Bovine Pleuropneumonia (CBPP) & - \\
\hline MIGS-4 & Geographic location & Cameroon (Afadé), Kenya (B237) & [3] \\
\hline MIGS-5 & Sample collection time & 1965 (Afadé), 1997 (B237) & - \\
\hline MIGS-4.1 & Latitude & Northern Cameroon (Afadé) 0103'S (B237) & \\
\hline MIGS-4.2 & Longitude & N/A (Afadé) 3705’E (B237) & \\
\hline MIGS-4.3 & Depth & N/A & \\
\hline MIGS-4.4 & Altitude & N/A (Afadé), 1631 m (B237) & \\
\hline
\end{tabular}

${ }^{a}$ Evidence codes - IDA: Inferred from Direct Assay; TAS: Traceable Author Statement (i.e., a direct report exists in the literature); NAS: Non-traceable Author Statement (i.e., not directly observed for the living, isolated sample, but based on a generally accepted property for the species, or anecdotal evidence). These evidence codes are from the Gene Ontology project [47]

of Pacific Biosciences R.S. (PacBio) sequencing (65,280 reads/2853 bp average read length) and Illumina MiSeq sequencing (7,078,010 reads/295 average read length) downsampled to cover 50 times the expected genome size. The sequencing errors of the long PacBio single-molecule reads were corrected with the shorter, high accuracy Illumina reads using the Celera Assembler (CA) pacbio correction module $\mathrm{PBcR}$ (version 7.0, [28]). The resulting corrected PacBio reads were randomly sampled to 25 genome fold and assembled using CA (version 7.0, [29]) and yielded 18 contigs with a total size of $1,278,455 \mathrm{bp}$. Eight contigs comprised the draft genome of strain Afadé.

The whole genome sequence of Mycoplasma mycoides subsp. mycoides strain B237 was obtained using PacBio sequencing (59,775 reads/2674 average read length). Pacbio reads were corrected with $\mathrm{PBcR}$ self-correction module. Corrected reads randomly sampled to 25 genome fold were assembled with $\mathrm{CA}$ and yielded 2 contigs with total size of $1,208,895$ bp. One long contigs comprises the entire genome and contained the other contig (5091 bp) in a repeat region. The final genome sequences had a 24-fold coverage for Afadé and 23-fold coverage for B237.

The contigs of both assemblies were aligned against the two Mycoplasma mycoides subsp. mycoides reference genomes of Gladysdale [8] and PG1 [7] available in Genbank (CP002107, NC_005364) using mummer [30] and we noticed that all small contigs $(<15,000 \mathrm{bp})$ aligned to places 


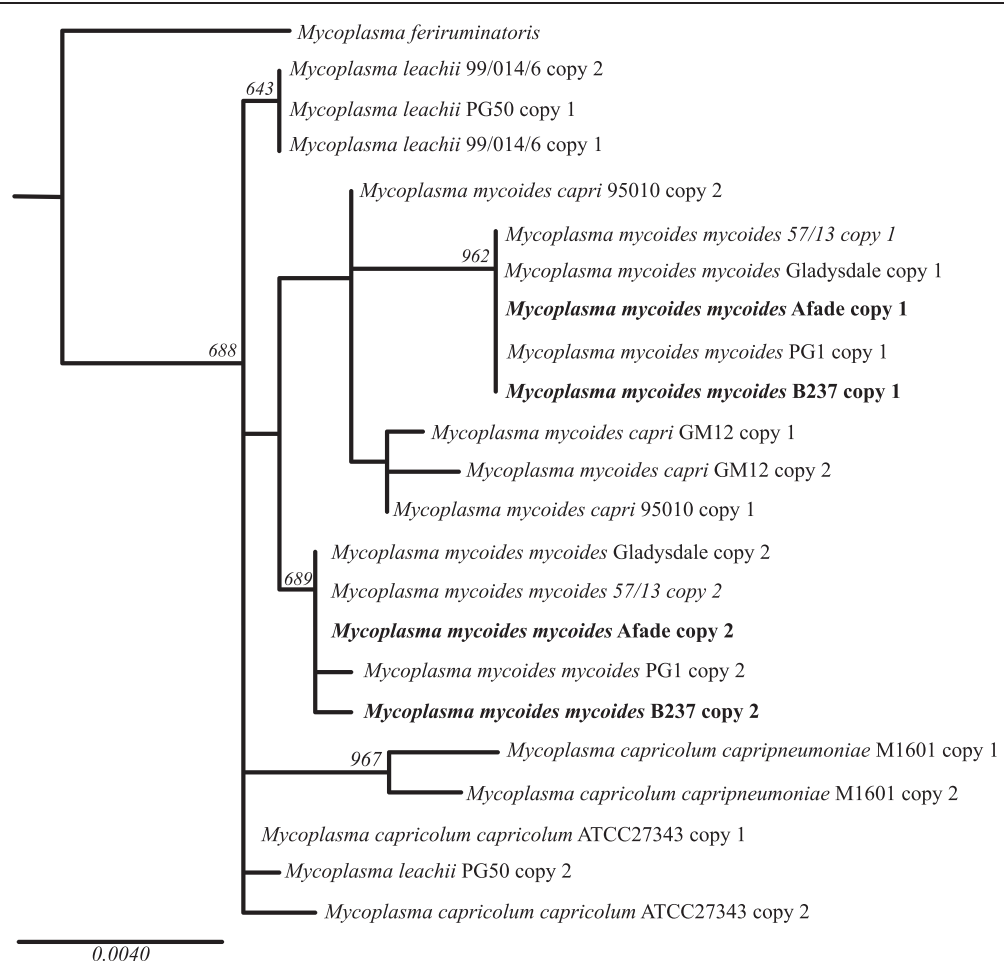

Fig. 2 (half page, 2 columns): Phylogenetic tree based on 16S rRNA sequences showing the relationship between Mycoplasma mycoides subsp. mycoides strains Afadé and B237 with members of the 'Mycoplasma mycoides cluster' and their closest relatives. The alignment length was 1,439 bp. The tree was generated with PhyML v.3.0 [48] using the HKY85 model of evolution and with 1,000 bootstrap values. Only boostrap values over 500 are shown.

already covered in other bigger contigs. On closer inspection, most of these contigs aligned to a previously characterized $26 \mathrm{~kb}$ region [11], consisting of a tandem repeat of three $8 \mathrm{~kb}$ segments, interspersed with transposon elements. Due to its repetitive nature, this $26 \mathrm{~kb}$ region was not clearly resolved during the assembly process. In order to resolve part of it, we were able to design unique primer pairs and amplify two long-range PCRs fragments of 4,800 and 5,200 bp respectively. For each genome, both Sanger derived sequences were aligned to the assembled genomes

Table 2 Project information

\begin{tabular}{llll}
\hline MIGS ID & Property & Term & Term \\
MIGS-31 & Finishing quality & High-quality draft & High-quality draft \\
\hline MIGS-28 & Libraries used & 1. Illumina Paired End 7,078,010 reads; & $\begin{array}{c}\text { 1. PacBio 59,775 reads; Average } \\
\text { read length 2674 bp }\end{array}$ \\
& & Average read length 295 bp; & Average insert size 725 bp. \\
& & 2. PacBio 65,280 reads, 2853 bp average \\
read length; & Illumina MiSeq, Pacific Biosciences R.S. & Illumina MiSeq, Pacific Biosciences R.S. \\
MIGS-29 & Sequencing platforms & 24X & 23X \\
MIGS-31.2 & Fold coverage & Celera Assembler v.7 & Celera Assembler v.7 \\
MIGS-30 & Assemblers & Prodigal & Prodigal \\
MIGS-32 & Gene calling method & LAEX00000000 & LAEW00000000 \\
& Genbank ID & 20-Mar-15 & 20-Mar-15 \\
& Date of Release & PRJNA272775 & PRJNA272471 \\
MIGS 13 & BIOPROJECT & ILRI_Azizi_biobank Strain Afadé & ILRI_Azizi_biobank Strain B237 \\
& Pource Material Identifier & Challenge strains of CBPP & Challenge strains of CBPP \\
\hline
\end{tabular}


before and after polishing with multiple iterations of the PacBio Quiver algorithm (version 0.9.0 [31]). We verified that in the regions covered by the Sanger sequences, all substitution mismatches were resolved by Quiver, however we manually fixed a few indels present in the post polishing alignment, which were not corrected by Quiver.

\section{Genome annotation}

Open reading frames (ORFs) were predicted using Prodigal 2.50 [32]. Functional annotation was produced by the Institute for Genome Sciences Analysis Engine [26].

We annotated the small contigs overlapping bigger ones described above separately and noticed that these contigs had more ambiguous characters and ORFs that were on average half the size of the corresponding ORFs in larger contigs (498 nt versus $920 \mathrm{nt}$ ). This was due to insertions and deletions. We therefore excluded the small contigs from the assemblies and report 1 contig for Mycoplasma mycoides subsp. mycoides strain B237 and 8 contigs for Mycoplasma mycoides subsp. mycoides strain Afadé.

We also reannotated the genomes of Mycoplasma mycoides subsp. mycoides strain PG1, Mycoplasma mycoides subsp. mycoides strain Gladysdale and Mycoplasma mycoides subsp. mycoides strain 57/13 using the same Engine, for ease of comparison.

\section{Genome properties}

The genomes of Mycoplasma mycoides subsp. mycoides strain Afadé and B237 have a total size of 1,190,241 bp and 1,203,804 bp, respectively. The GC-content of both genomes is $23.9 \%$. Both strains have two copies of the $12 \mathrm{~kb}$ and $13 \mathrm{~kb}$ repeat described in [11], the difference in size between the two genomes is therefore not due to a missing copy in Afadé.

A total of 1,124 ORFs as well as 30 tRNA and 2 copies of the 23S, $16 \mathrm{~S}$ and $5 \mathrm{~S}$ rRNA operons were predicted. The average gene length is $920 \mathrm{bp}$ and $927 \mathrm{bp}$ for Afadé and B237, respectively. The coding density of the genome is $86.7 \%$. Signal peptides were detected using pSortb v3.0 [33] and LipoP v1.0 [34]. Transmembrane helices were detected with the TMHMM server v2.0 [35, 36]. CRISPR repeats were searched with the CRISPR Finding program online. The properties and the statistics of both genomes are summarized in Tables 3, 4, 5 .

\section{Insights from the genome sequence}

The genomes of the two African strains Mycoplasma mycoides subsp. mycoides Afadé and B237 were compared to the three previously sequenced Mycoplasma mycoides subsp. mycoides strains Gladysdale, PG1 and 57/13 using CloVR and Sybil [37, 38]. Figure 3 shows a synteny gradient of the aligned genomes. Although there are a high number of transposable elements in all genomes, no major rearrangements have been observed. These results fit well with
Table 3 Summary of the B237 and Afadé genomes: one circular chromosome

\begin{tabular}{llll}
\hline Strain & Size $(\mathrm{Mb})$ & Topology & INSDC identifier \\
\hline Afadé & $1,190,241$ & 8 contigs & LAEX000000000 \\
B237 & $1,203,804$ & Circular & LAEW00000000 \\
\hline
\end{tabular}

the very recent emergence of the pathogen, estimated to be as young as 300 years, and the narrow host specificity of Mycoplasma mycoides subsp. mycoides [5].

The core genome length is $1,148,950 \mathrm{bp}$. A total of 773 SNPs were identified when comparing the five core genomes. Only 72 SNPs distinguish B237 from Afadé. Two hundred and sixty six SNPs separate the Australian and European strains Gladysdale and 57/13. PG1 is the most distant from the other four genomes with $399,483,465$ to 425 SNPs when compared to Afadé, Gladysdale, 57/13 and B237, respectively. This confirms previous reports [5].

We looked for homologs to the Cytadhesin proteins P1, P30, P40. P65, P90, HMW1 and HMW3 from Mycoplasma pneumoniae in the Afadé and B237 proteomes using blastp. No significant hits were found for any of the proteins. Other proteins might be involved in the adhesion process and will need to be identified and characterized.

Table 4 Nucleotide content and gene count levels of the genome

\begin{tabular}{|c|c|c|c|c|}
\hline \multirow{2}{*}{$\begin{array}{l}\text { Strain } \\
\text { Attribute }\end{array}$} & \multicolumn{2}{|l|}{ Afadé } & \multicolumn{2}{|l|}{ B237 } \\
\hline & Value & $\begin{array}{l}\% \text { of } \\
\text { total }^{\mathrm{a}}\end{array}$ & Value & $\begin{array}{l}\% \text { of } \\
\text { total }\end{array}$ \\
\hline Genome Size (bp) & $1,190,241$ & 100.00 & $1,203,804$ & 100.00 \\
\hline DNA coding (bp) & $1,032,189$ & 86.70 & $1,043,698$ & 86.70 \\
\hline DNA G + C (bp) & 284,536 & 23.90 & 287,709 & 23.90 \\
\hline DNA scaffolds & na & na & na & na \\
\hline Total genes & 1156 & 100.00 & 1157 & 100.00 \\
\hline Protein-coding genes & 1120 & 96.89 & 1121 & 96.89 \\
\hline rRNA genes & 6 & 5.19 & 6 & 5.19 \\
\hline Pseudogenes & 0 & 0 & 0 & 0 \\
\hline Genes in internal clusters & na & na & na & na \\
\hline $\begin{array}{l}\text { Genes with function } \\
\text { prediction }\end{array}$ & 687 & 59.43 & 693 & 59.90 \\
\hline Genes assigned to COGs & 681 & 58.71 & 693 & 59.9 \\
\hline Genes with Pfam domains & 389 & 33.65 & 355 & 30.68 \\
\hline Genes with signal peptides & 74 & 6.40 & 74 & 6.40 \\
\hline $\begin{array}{l}\text { Genes with transmembrane } \\
\text { helices }\end{array}$ & 234 & 20.24 & 241 & 20.83 \\
\hline CRISPR repeats & 0.00 & 0.00 & 0.00 & 0.00 \\
\hline
\end{tabular}

The total is based on either the size of the genome in base pairs or the total number of protein coding genes in the annotated genome 
Table 5 Number of genes associated with the 25 general COG functional categories

\begin{tabular}{|c|c|c|c|c|c|}
\hline Code & Value & $\%$ of total ${ }^{a}$ & Value & $\%$ of total ${ }^{a}$ & Description \\
\hline Strain & Afadé & & B237 & & \\
\hline J & 141 & 12.19 & 139 & 12.01 & Translation, ribosomal structure and biogenesis \\
\hline A & 0 & 0.00 & 0 & 0.00 & RNA processing and modification \\
\hline K & 34 & 2.94 & 34 & 2.94 & Transcription \\
\hline L & 50 & 4.32 & 50 & 4.32 & Replication, recombination and repair \\
\hline B & 0 & 0.00 & 0 & 0.00 & Chromatin structure and dynamics \\
\hline D & 9 & 0.78 & 8 & 0.69 & Cell cycle control, Cell division, chromosome partitioning \\
\hline Y & 0 & 0.00 & 0 & 0.00 & Nuclear structure \\
\hline V & 12 & 1.04 & 13 & 1.12 & Defense mechanisms \\
\hline $\mathrm{T}$ & 15 & 1.30 & 15 & 1.30 & Signal transduction mechanisms \\
\hline M & 27 & 2.34 & 33 & 2.85 & Cell wall/membrane biogenesis \\
\hline N & 8 & 0.69 & 9 & 0.78 & Cell motility \\
\hline Z & 0 & 0.00 & 0 & 0.00 & Cytoskeleton \\
\hline W & 0 & 0.00 & 0 & 0.00 & Extracellular structures \\
\hline U & 5 & 0.43 & 6 & 0.52 & Intracellular trafficking and secretion \\
\hline $\mathrm{O}$ & 26 & 2.25 & 25 & 2.16 & Posttranslational modification, protein turnover, chaperones \\
\hline C & 29 & 2.51 & 28 & 2.42 & Energy production and conversion \\
\hline G & 71 & 6.14 & 70 & 6.05 & Carbohydrate transport and metabolism \\
\hline $\mathrm{E}$ & 44 & 3.81 & 42 & 3.63 & Amino acid transport and metabolism \\
\hline $\mathrm{F}$ & 32 & 2.77 & 32 & 2.77 & Nucleotide transport and metabolism \\
\hline H & 30 & 2.60 & 29 & 2.51 & Coenzyme transport and metabolism \\
\hline । & 14 & 1.21 & 14 & 1.21 & Lipid transport and metabolism \\
\hline$P$ & 39 & 3.37 & 48 & 4.15 & Inorganic ion transport and metabolism \\
\hline Q & 1 & 0.09 & 1 & 0.09 & Secondary metabolites biosynthesis, transport and catabolism \\
\hline $\mathrm{R}$ & 45 & 3.89 & 45 & 3.89 & General function prediction only \\
\hline S & 6 & 0.52 & 6 & 0.52 & Function unknown \\
\hline- & 101 & 8.74 & 105 & 9.08 & Other COG categories \\
\hline- & 442 & 38.24 & 431 & 37.25 & Not in COGs \\
\hline
\end{tabular}

${ }^{a}$ The total is based on the total number of protein coding genes in the annotated genome

\section{Conclusions}

The genomes of the two African strains as expected differ from the laboratory type strain PG1, the European outbreak strain 57/13 and the Australian outbreak strain Gladysdale. Therefore these genome sequences should be included in subsequent genome comparisons and 'omics' studies. The presence of protrusions and branching phenotypes in these two Mycoplasmas but the absence of protein encoding genes similar to the ones characterized in Mycoplasma pneumoniae indicates that other/novel proteins in the Mycoplasma genomes encode the development of protrusions and branching.

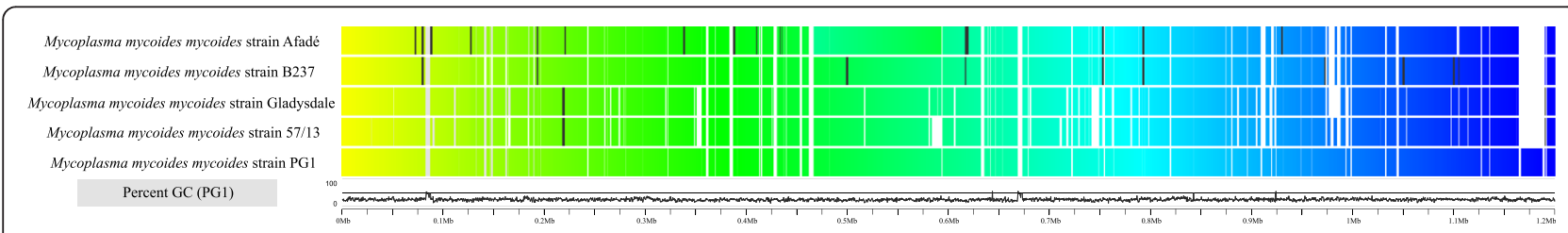

Fig. 3 (quarter page, two columns): Synteny gradient display for the four available Mycoplasma mycoides subsp. mycoides genomes, using PG1 as a reference. A white bar in the reference denotes a region with no gene annotation. The matching genes are colored based on the relative position in their respective genomes (yellow for the beginning and blue for the end). Genes shown in black are part of a paralogous cluster in their respective genome and therefore do not have a single native location. The GC-content in \% is plotted for the reference genome 


\section{Appendix}

Table 6 Associated MIGS record

\begin{tabular}{|c|c|c|c|}
\hline MIGS-ID & field name & description & description \\
\hline Strain & & Afadé & B237 \\
\hline MIGS-1 & Submit to INSDC/Trace archives & LAEX00000000 & LAEW00000000 \\
\hline 1.1 & PID & PRJNA272471 & PRJNA272775 \\
\hline 1.2 & Trace Archive & & \\
\hline MIGS-2 & MIGS CHECK LIST TYPE & & \\
\hline MIGS-3 & Project Name & $\begin{array}{l}\text { High quality draft genomes of the } \\
\text { Mycoplasma mycoides subsp. mycoides } \\
\text { challenge strains Afadé and B237 }\end{array}$ & $\begin{array}{l}\text { High quality draft genomes of the } \\
\text { Mycoplasma mycoides subsp. mycoides } \\
\text { challenge strains Afadé and B237 }\end{array}$ \\
\hline MIGS-4 & Geographic Location & Cameroon & Kenya \\
\hline 4.1 & Latitude & not reported & $01^{\circ} 03^{\prime} \mathrm{S}$ \\
\hline 4.2 & Longitude & not reported & $37^{\circ} 05^{\prime} \mathrm{E}$ \\
\hline 4.3 & Depth & na & na \\
\hline 4.4 & Altitude & not reported & $1631 \mathrm{~m}$ \\
\hline MIGS-5 & Time of Sample collection & not reported & not reported \\
\hline MIGS-6 & Habitat (EnvO) & Respiratory tract & Respiratory tract \\
\hline 6.1 & temperature & 38.5 & 38.5 \\
\hline 6.2 & $\mathrm{pH}$ & $6.5-8.5$ & $6.5-8.5$ \\
\hline 6.3 & salinity & $0.09 \%$ & $0.09 \%$ \\
\hline 6.4 & chlorophyll & na & na \\
\hline 6.5 & conductivity & na & na \\
\hline 6.6 & light intensity & na & na \\
\hline 6.7 & dissolved organic carbon (DOC) & na & na \\
\hline 6.8 & current & na & na \\
\hline 6.9 & atmospheric data & na & na \\
\hline 6.1 & density & na & na \\
\hline 6.11 & alkalinity & na & na \\
\hline 6.12 & dissolved oxygen & na & na \\
\hline 6.13 & particulate organic carbon (POC) & na & na \\
\hline 6.14 & phosphate & na & na \\
\hline 6.15 & nitrate & na & na \\
\hline 6.16 & sulfates & na & na \\
\hline 6.17 & sulfides & na & na \\
\hline 6.18 & primary production & na & na \\
\hline MIGS-7 & $\begin{array}{l}\text { Subspecific genetic } \\
\text { lineage }\end{array}$ & strain & strain \\
\hline MIGS-9 & Number of replicons & 1 & 1 \\
\hline MIGS-10 & Extrachromosomal elements & none & none \\
\hline MIGS-11 & Estimated Size & $1.2 \mathrm{MB}$ & $1.2 \mathrm{Mb}$ \\
\hline MIGS-12 & Reference for biomaterial or Genome report & primary genome report & primary genome report \\
\hline MIGS-13 & Source material identifiers & & \\
\hline MIGS-14 & Known Pathogenicity & Contagious Bovine Pleuropneumonia & Contagious Bovine Pleuropneumonia \\
\hline MIGS-15 & Biotic Relationship & obligate parasite & obligate parasite \\
\hline
\end{tabular}


Table 6 Associated MIGS record (Continued)

\begin{tabular}{|c|c|c|c|}
\hline MIGS-16 & Specific Host & Cattle & Cattle \\
\hline MIGS-17 & Host specificity or range (taxid) & 9903 & 9903 \\
\hline MIGS-18 & Health status of Host & Sick & Sick \\
\hline MIGS-19 & Trophic Level & heterotroph & heterotroph \\
\hline MIGS-22 & Relationship to Oxygen & anaerobic & anaerobic \\
\hline MIGS-23 & Isolation and Growth conditions & $\begin{array}{l}\text { optional: reference may be provided if } \\
\text { applicable }\end{array}$ & $\begin{array}{l}\text { optional: reference may be provided if } \\
\text { applicable }\end{array}$ \\
\hline MIGS-27 & Nucleic acid preparation & & \\
\hline MIGS-28 & Library construction & & \\
\hline 28.1 & Library size & & \\
\hline 28.2 & Number of reads & & \\
\hline 28.3 & vector & & \\
\hline MIGS-29 & Sequencing method & Illumina Miseq 300PE and PacBio & PacBio \\
\hline MIGS-30 & Assembly & & \\
\hline 30.1 & Assembly method & Celera assembler v7.0 & Celera assembler v7.0 \\
\hline 30.2 & estimated error rate & & \\
\hline 30.3 & method of calculation & & \\
\hline MIGS-31 & Finishing strategy & High-quality draft & High-quality draft \\
\hline 31.1 & Status & & \\
\hline 31.2 & coverage & $25 x$ & $25 x$ \\
\hline 31.3 & contigs & 7 & 1 \\
\hline MIGS-32 & Relevant SOPs & & \\
\hline MIGS-33 & Relevant e-resources & & \\
\hline
\end{tabular}

\section{Abbreviations}

CBPP: Contagious bovine pleuropneumonia.

\section{Competing interests}

The authors declare that they have no competing interests.

\section{Authors' contributions}

AF, ISC, HG, JW, ML, SN analyzed the data. ES, RAM, JJ, JH, JM, JF performed laboratory work. HW provided reagents. SV provided tools and protocols. AF, JJ drafted the manuscript. All authors read and approved the final manuscript

\section{Acknowledgments}

This work was funded by the German Federal Ministry for Economic Cooperation and Development (contract 81121408, project No 09.7860 .1 001.00). The Centrum of International Migration (CIM) supported Anne Fischer. Elise Schieck was supported by BMZ (grant project No.: 09.7860.1001.00). Joerg Jores and Sanjay Vashee were supported partly by the National Science Foundation under Grant No. IOS-1110151. Infrastructure of PacBio sequencing was financed by the Fonds de la Loterie Romande. The functional annotation was conducted using the IGS Annotation Engine, University of Maryland School of Medicine. We thank Gerhard Preiss for excellent maintenance and help with electron microscopes and Andrea Kofink-Germershausen and Sabine Fiedler for excellent technical assistance We thank Cecilia Muriuki for her help in determining the growth temperature and Herve Tettelin and Sonia Agrawal for guidance on the use of clovR. All authors read and approved the manuscript.

\section{Nucleotide sequence accession numbers}

This Whole Genome Shotgun projects for Afadé and B237 have been deposited at DDBJ/EMBL/GenBank under accession numbers LAEX00000000, LAEW00000000 respectively. The versions described in this paper are the first versions.

\begin{abstract}
Author details
${ }^{1}$ International Livestock Research Institute, PO Box 3070900100 Nairobi, Kenya. ${ }^{2}$ International Centre for Insect Physiology and Ecology, PO Box 30772, 00100 Nairobi, Kenya. ${ }^{3}$ Institute for Genome Sciences, University of Maryland School of Medicine, 801 W. Baltimore Street BioPark II, 21201 Baltimore, MD, USA. Institute of Functional and Applied Anatomy, Hannover Medical School, Hannover, Germany. ${ }^{5}$ Biomedical Research in Endstage and Obstructive Lung Disease Hannover (BREATH), Member of the German Center for Lung Research (DZL), Hannover, Germany. ${ }^{6}$ REBIRTH Cluster of Excellence, Hannover, Germany. ${ }^{7}$ Department of Animal Breeding and Genetics, SLU Global Bioinformatics Centre, Swedish University of Agricultural Sciences, SE75007 Uppsala, Sweden. ${ }^{8}$ Kenya Agricultural and Livestock Research Organization (KALRO) Muguga, PO Box 32-00902, Kikuyu, Kenya. ${ }^{9}$ Department of Food Science, Cornell University, Ithaca, NY, USA. ${ }^{10} \mathrm{~J}$. Craig Venter Institute, 9704 Medical Center Drive, 20850 Rockville, MD, USA.

${ }^{11}$ Lausanne Genomic Technologies Facility Center for Integrative Genomics, University of Lausanne, 1015 Lausanne, Switzerland. ${ }^{12}$ Institute for Microbiology, Department of Infectious Diseases, University of Veterinary Medicine Hannover, Hannover, Germany. ${ }^{13}$ Institute of Veterinary Bacteriology, University of Bern, $\mathrm{CH}-3001$ Bern, Switzerland.
\end{abstract}

Received: 9 April 2015 Accepted: 16 September 2015

Published online: 29 October 2015

\section{References}

1. Manso-Silvan L, Vilei EM, Sachse K, Djordjevic SP, Thiaucourt F, Frey J. Mycoplasma leachii sp. nov. as a new species designation for Mycoplasma sp. bovine group 7 of Leach, and reclassification of Mycoplasma mycoides subsp. mycoides LC as a serovar of Mycoplasma mycoides subsp. capri. Int J Syst Evol Microbiol. 2009;59(Pt 6):1353-8.

2. Krieg NR, Ludwig W, Whitman WB, Hedlund BP, Paster BJ, Staley JT, et al. Bergey's manual of systematic bacteriology. Volume 4. 2nd ed. New York: Springer; 2010. p. 948. 
3. de Haller A. De Lue Bovilla Agri Bernensis Commentatio. Novi commentarii Societatis Regiae Scientiarum Gottingensis. Goettingen State University, Goettingen, Germany 1773:25-43.

4. Hutyra F, Marek J, Manninger R. Diseases of Domestic Animals. Contagious Bovine Pleuropneumonia. Greig JR, Mohler JR, Eichhorn A, editors. London: Balliere, Tindal and Cox; 1938.

5. Dupuy V, Manso-Silvan L, Barbe V, Thebault P, Dordet-Frisoni E, Citti C, et al. Evolutionary history of contagious bovine pleuropneumonia using next generation sequencing of Mycoplasma mycoides subsp. mycoides "Small Colony". PLoS One. 2012;7(10):e46821.

6. Fischer A, Shapiro B, Muriuki C, Heller M, Schnee C, Bongcam-Rudloff E, et al. The origin of the 'Mycoplasma mycoides Cluster' coincides with domestication of ruminants. PLoS One. 2012;7(4), e36150.

7. Westberg J, Persson A, Holmberg A, Goesmann A, Lundeberg J, Johansson $K E$, et al. The genome sequence of Mycoplasma mycoides subsp. mycoides SC type strain $P G 1^{\top}$, the causative agent of contagious bovine pleuropneumonia (CBPP). Genome Res. 2004;14(2):221-7.

8. Wise KS, Calcutt MJ, Foecking MF, Madupu R, DeBoy RT, Roske K, et al. Complete genome sequences of Mycoplasma leachii strain PG50T and the pathogenic Mycoplasma mycoides subsp. mycoides small colony biotype strain Gladysdale. J Bacteriol. 2012;194(16):4448-9.

9. Orsini M, Krasteva I, Marcacci M, Ancora M, Ciammaruconi A, Gentile B, et al. Whole-Genome Sequencing of Mycoplasma mycoides subsp. mycoides Italian Strain 57/13, the Causative Agent of Contagious Bovine Pleuropneumonia. Genome Announc 2015;3(2).

10. Bischof DF, Janis C, Vilei EM, Bertoni G, Frey J. Cytotoxicity of Mycoplasma mycoides subsp. mycoides small colony type to bovine epithelial cells. Infect Immun. 2008;76(1):263-9.

11. Bischof DF, Vilei EM, Frey J. Genomic differences between type strain PG1 and field strains of Mycoplasma mycoides subsp. mycoides small-colony type. Genomics. 2006;88(5):633-41.

12. Griffin RM. Antigenic relationships among strains of Mycoplasma mycoides var. mycoides, M. capri and M. laidlawii revealed by complement-fixation tests. J Gen Microbiol. 1969:57(1):131-42.

13. Jores J, Mariner JC, Naessens J. Development of an improved vaccine for contagious bovine pleuropneumonia: an African perspective on challenges and proposed actions. Vet Res. 2013;44(1):122.

14. Jores J, Nkando I, Sterner-Kock A, Haider W, Poole J, Unger H, et al. Assessment of in vitro interferon-gamma responses from peripheral blood mononuclear cells of cattle infected with Mycoplasma mycoides ssp. mycoides small colony type. Vet Immunol Immunopathol. 2008;124(1-2):192-7.

15. Mulongo MM, Frey J, Smith K, Schnier C, Wesonga H, Naessens J, et al. Cattle immunized against the pathogenic L-alpha-glycerol-3-phosphate oxidase of Mycoplasma mycoides subs. mycoides fail to generate neutralizing antibodies and succumb to disease on challenge. Vaccine. 2013;31(44):5020-5.

16. Nkando I, Ndinda J, Kuria J, Naessens J, Mbithi F, Schnier C, et al. Efficacy of two vaccine formulations against contagious bovine pleuropneumonia (CBPP) in Kenyan indigenous cattle. Res Vet Sci. 2012;93(2):568-73.

17. Sacchini F, Naessens J, Awino E, Heller M, Hlinak A, Haider W, et al. A minor role of CD4+ T lymphocytes in the control of a primary infection of cattle with Mycoplasma mycoides subsp. mycoides. Vet Res. 2011;42(1):77.

18. Schieck E, Liljander A, Hamsten C, Gicheru N, Scacchia M, Sacchini F, et al. High antibody titres against predicted Mycoplasma surface proteins do not prevent sequestration in infected lung tissue in the course of experimental contagious bovine pleuropneumonia. Vet Microbiol. 2014;172(1-2):285-93.

19. Reynolds ES. The use of lead citrate at high $\mathrm{pH}$ as an electron-opaque stain in electron microscopy. J Cell Biol. 1963;17:208-12.

20. Hegermann J, Herrmann R, Mayer F. Cytoskeletal elements in the bacterium Mycoplasma pneumoniae. Naturwissenschaften. 2002;89(10):453-8.

21. Krause DC. Mycoplasma pneumoniae cytadherence: unravelling the tie that binds. Mol Microbiol. 1996;20(2):247-53.

22. Regula JT, Boguth G, Gorg A, Hegermann J, Mayer F, Frank R, et al. Defining the mycoplasma 'cytoskeleton': the protein composition of the Triton X-100 insoluble fraction of the bacterium Mycoplasma pneumoniae determined by 2-D gel electrophoresis and mass spectrometry. Microbiology. 2001;147(Pt 4):1045-57.

23. Seto S, Layh-Schmitt G, Kenri T, Miyata M. Visualization of the attachment organelle and cytadherence proteins of Mycoplasma pneumoniae by immunofluorescence microscopy. J Bacteriol. 2001;183(5):1621-30.
24. Yaya A, Manso-Silvan L, Blanchard A, Thiaucourt F. Genotyping of Mycoplasma mycoides subsp. mycoides SC by multilocus sequence analysis allows molecular epidemiology of contagious bovine pleuropneumonia. Vet Res. 2008;39(2):14.

25. Jores J, Fischer A, Sirand-Pugnet $P$, Thomann A, Liebler-Tenorio EM, Schnee C, et al. Mycoplasma feriruminatoris sp. nov., a fast growing Mycoplasma species isolated from wild Caprinae. Syst Appl Microbiol. 2013;36(8):533-8.

26. Galens K, Orvis J, Daugherty S, Creasy HH, Angiuoli S, White O, et al. The IGS standard operating procedure for automated prokaryotic annotation. Stand Genomic Sci. 2011;4(2):244-51.

27. Field D, Garrity G, Gray T, Morrison N, Selengut J, Sterk P, et al. The minimum information about a genome sequence (MIGS) specification. Nat Biotechnol. 2008;26(5):541-7.

28. Koren S, Schatz MC, Walenz BP, Martin J, Howard JT, Ganapathy G, et al. Hybrid error correction and de novo assembly of single-molecule sequencing reads. Nat Biotechnol. 2012;30(7):693-700.

29. Miller JR, Delcher AL, Koren S, Venter E, Walenz BP, Brownley A, et al. Aggressive assembly of pyrosequencing reads with mates. Bioinformatics. 2008;24(24):2818-24.

30. Kurtz S, Phillippy A, Delcher AL, Smoot M, Shumway M, Antonescu C, et al Versatile and open software for comparing large genomes. Genome Biol. 2004;5(2):R12.

31. Chin CS, Alexander DH, Marks P, Klammer AA, Drake J, Heiner C, et al. Nonhybrid, finished microbial genome assemblies from long-read SMRT sequencing data. Nat Methods. 2013;10(6):563-9.

32. Hyatt D, Chen GL, Locascio PF, Land ML, Larimer FW, Hauser LJ. Prodigal: prokaryotic gene recognition and translation initiation site identification. BMC Bioinformatics. 2010;11:119.

33. Yu NY, Wagner JR, Laird MR, Melli G, Rey S, Lo R, et al. PSORTb 3.0: improved protein subcellular localization prediction with refined localization subcategories and predictive capabilities for all prokaryotes. Bioinformatics. 2010;26(13):1608-15.

34. Juncker AS, Willenbrock $H$, Von Heijne G, Brunak S, Nielsen H, Krogh A. Prediction of lipoprotein signal peptides in Gram-negative bacteria. Protein Sci. 2003;12(8):1652-62.

35. Krogh A, Larsson B, von Heijne G, Sonnhammer EL. Predicting transmembrane protein topology with a hidden Markov model: application to complete genomes. J Mol Biol. 2001;305(3):567-80.

36. Sonnhammer EL, von Heijne G, Krogh A. A hidden Markov model for predicting transmembrane helices in protein sequences. Proc Int Conf Intell Syst Mol Biol. 1998;6:175-82.

37. Angiuoli SV, Matalka M, Gussman A, Galens K, Vangala M, Riley DR, et al. CloVR: a virtual machine for automated and portable sequence analysis from the desktop using cloud computing. BMC Bioinformatics. 2011;12:356

38. Riley DR, Angiuoli SV, Crabtree J, Dunning Hotopp JC, Tettelin H. Using Sybi for interactive comparative genomics of microbes on the web. Bioinformatics. 2012;28(2):160-6.

39. Woese CR, Kandler O, Wheelis ML. Towards a natural system of organisms: proposal for the domains Archaea, Bacteria, and Eucarya. Proc Natl Acad Sci U S A. 1990;87(12):4576-9.

40. Schleifer K-H. Phylum XIII.Firmicutes. Paul De Vos, George M. Garrity Dorothy Jones, Noel R. Krieg, Wolfgang Ludwig, Fred A. Rainey, Karl-Heinz Schleifer, Whitman WB, editors. Bergey's Manual of Systematic Bacteriology. New York: Springer; 2009;3

41. Brown DR, May M, Bradbury JR, Johansson K-E. Phylum XVI. Tenericutes, Bergey's Manual of Systematic Bacteriology. Krieg NR, Ludwig W, Whitman W, Hedlund BP, Paster BJ, Staley JT, Ward N, Brown D, Parte A, editors. New York: Springer; 2010;4.

42. Ludwig W, Euzéby J, Whitman WB. Road map of the phyla Bacteroidetes, Spirochaetes, Tenericutes (Mollicutes), Acidobacteria, Fibrobacteres, Fusobacteria, Dictyoglomi, Gemmatimonadetes, Lentisphaerae, Verrucomicrobia, Chlamydiae, and Planctomycetes. Krieg NR, Ludwig W, Whitman W, Hedlund BP, Paster BJ, Staley JT, Ward N, Brown D, Parte A, editors. New York: Springer; 2010

43. Murray RGE. Bergey's Manual of Systematic Bacteriology. The Higher Taxa, or, a Place for Everything...? Garrity G, Boone DR, Castenholz RW, editors. Baltimore: The William and Wilkins co.; 1984;1.

44. Ed L. Validation of the publication of new names and new combinations previously effectively published outside the IJSB. Int J Syst Bacteriol. 1984;34:355-7. 
45. Edward DG, Freundt EA. Type strains of Species of the Order Mycoplasmatales, Including Designation of Neotypes for Mycoplasme mycoides subsp. mycoides, Mycoplasma agalactiae subsp. agalactiae, and Mycoplasma arthritidis. Int J Syst Bacteriol. 1973;23(1):55-61.

46. Freundt EA. The classification of the pleuropneumonia group of organisms (Borrelomycetales). Int Bull Bacteriological Nomenclature and Taxonomy. 1955;5(2):67-78.

47. Ashburner M, Ball CA, Blake JA, Botstein D, Butler H, Cherry JM, et al. Gene ontology: tool for the unification of biology. The Gene Ontology Consortium. Nat Genet. 2000;25(1):25-9.

48. Guindon S, Dufayard JF, Lefort V, Anisimova M, Hordijk W, Gascuel O. New algorithms and methods to estimate maximum-likelihood phylogenies: assessing the performance of PhyML 3.0. Syst Biol. 2010;59(3):307-21.

\section{Submit your next manuscript to BioMed Central and take full advantage of:}

- Convenient online submission

- Thorough peer review

- No space constraints or color figure charges

- Immediate publication on acceptance

- Inclusion in PubMed, CAS, Scopus and Google Scholar

- Research which is freely available for redistribution 